$\begin{array}{lll}\text { 堀川 } & \text { 敬太郎**. 小谷 } \text { 祐貴***. 小椋 智**** } \\ \text { 廣瀬 } & \text { 明夫****. 高橋 誠 } * * * * \text {. 小林 秀敏** }\end{array}$

Journal of The Japan Institute of Light Metals, Vol. 65, No. 10 (2015), 498-502

(C) 2015 The Japan Institute of Light Metals

\title{
Enhanced age hardening in an Al-Mg-Si alloy using high-speed compression*
}

\author{
Keitaro HORIKAWA **, Yuki KITANI***, Tomo OGURA**** \\ Akio HIROSE****, Makoto TAKAHASHI***** and Hidetoshi KOBAYASHI**
}

\begin{abstract}
The age hardening of an $\mathrm{Al}-\mathrm{Mg}-\mathrm{Si}$ alloy was examined by the effect of high-speed $\left(10^{5} \mathrm{~s}^{-1}\right)$ compression prior to aging. The enhancement of the age hardening is brought about by the formation of vacancy clusters during highspeed compression. High resolution transmission electron microscopy reveals that these vacancy clusters form stacking fault tetrahedra. Following peak aging, vacancy clusters and aging precipitates coexist in the grain interior. The high aging hardness obtained following high-speed compression is most probably due to the combined effects of vacancy and precipitation hardening.
\end{abstract}

(Received June 25, 2015 Accepted July 21，2015)

Keywords: aluminum-magnesium-silicon alloy, vacancy cluster, high-speed deformation, age hardening

\section{1. 緒言}

アルミニウムおよびアルミニウム合金は, $\mathrm{Cu}$ や $\mathrm{Ni}$ な゙ の金属などと比べて積層欠陥エネルギーが高いため，転 位の反応によって生じる積層欠陥四面体型の点欠陥集合 体（Stacking Fault Tetrahedron, SFT）は，通常速度（ひずみ 速度 $10^{-1} \mathrm{~s}^{-1}$ 以下）の塑性変形で形成されることはないと考

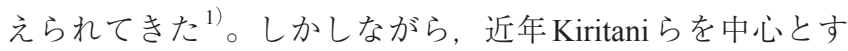
るグループによって，アルミニウムやアルミニウム合金で あってもひずみ速度 $10^{5} \mathrm{~s}^{-1}$ を超える高速度で塑性変形を与 えると大量のSFTが形成されることが報告されている ${ }^{2) \sim 4) 。 ~}$ Kiritaniらは，アルミニウム合金に高速度で圧縮変形を与え， SFTが大量生成される状況においては転位密度の増加も顕著 に抑制されていることを実験的に示している5 ${ }^{5)}$ 。これらの 結果をもとに，アルミニウム合金の高速変形で観察される点 欠陷集合体は，材料内部で転位の運動が制限されるような高 い内部応力状態にあるときに生成すると考えられている。

鍛造，押出，圧延など，通常速度の塑性変形を用いて材料 の組織を制御する手法は工業的にも数多く利用されている。
実用化されている塑性加工プロセスは，通常ひずみ速度で $10^{-1} \mathrm{~s}^{-1}$ 程度以下の低速度で行われるのが多く, その際の材 料の機械的特性はひずみ (転位) 強化で高められている。低 速度の塑性変形で生じる転位は, 時効析出相の粗大な不均一 析出のサイトを与えやすく, 強化に寄与する結晶粒内での微 細な均一析出を減少させることから, 低速度の塑性変形の付 与は, アルミニウム合金の時効析出現象に対しては負の影響 を与えることが多いことが広く認識されている。つまり，転 位によるひずみ強化と析出強化の完全な重畳作用を達成する のは困難な状況にある。一方, 高速変形で導入される, 転位 とは異なる格子欠陥であるSFTをアルミニウム合金の組織制 御に応用する研究はこれまで行われていない。アルミニウム 材料の高速変形で報告 ${ }^{7)}$ されている SFT はサイズが数ナノ メートル程度と極微小であるため, 析出強化に及ぼす負の影 響は転位と比べると低いものと予想される。さらに, この微 小なSFTの大量生成はボイド強化と類似して, それ自体が強 化因子として作用することも考えられる ${ }^{7)}$ 。そこで本研究で は, Al-Mg-Si系合金の時効硬化特性と組織形成に及ぼす高 速圧縮変形の影響を調査した。

\footnotetext{
*本論文は Materials Transactions, Vol. 56, No. 7 (2015),pp. 1058-1062に掲載したものである。

**大阪大学 大学院基礎工学研究科 機能創成専攻（勇560-8531 大阪府豊中市待兼山町 1-3） Department of Mechanical Science and Bioengineering, Graduate School of Engineering Science, Osaka University (1-3 Machikaneyama, Toyonaka-shi, Osaka 560-8531) E-mail: horikawa@me.es.osaka-u.ac.jp

***大阪大学 大学院基礎工学研究科 機能創成専攻 大学院生（豊中市）〔現在：三菱重工業株式会社〕 Graduate Student, Graduate School of Engineering Science, Osaka University (Toyonaka-shi, Osaka)〔Present: Mitsubishi Heavy Industry, Ltd.〕

****大阪大学 大学院工学系研究科 生産科学専攻（吹田市） Division of Material and Manufacturing Science, Graduate School of Engineering, Osaka University (Suita-shi, Osaka)

*****大阪大学 接合科学研究所（茨木市） Joining and Welding Research Institute, Osaka University (Ibaraki-shi, Osaka)
} 

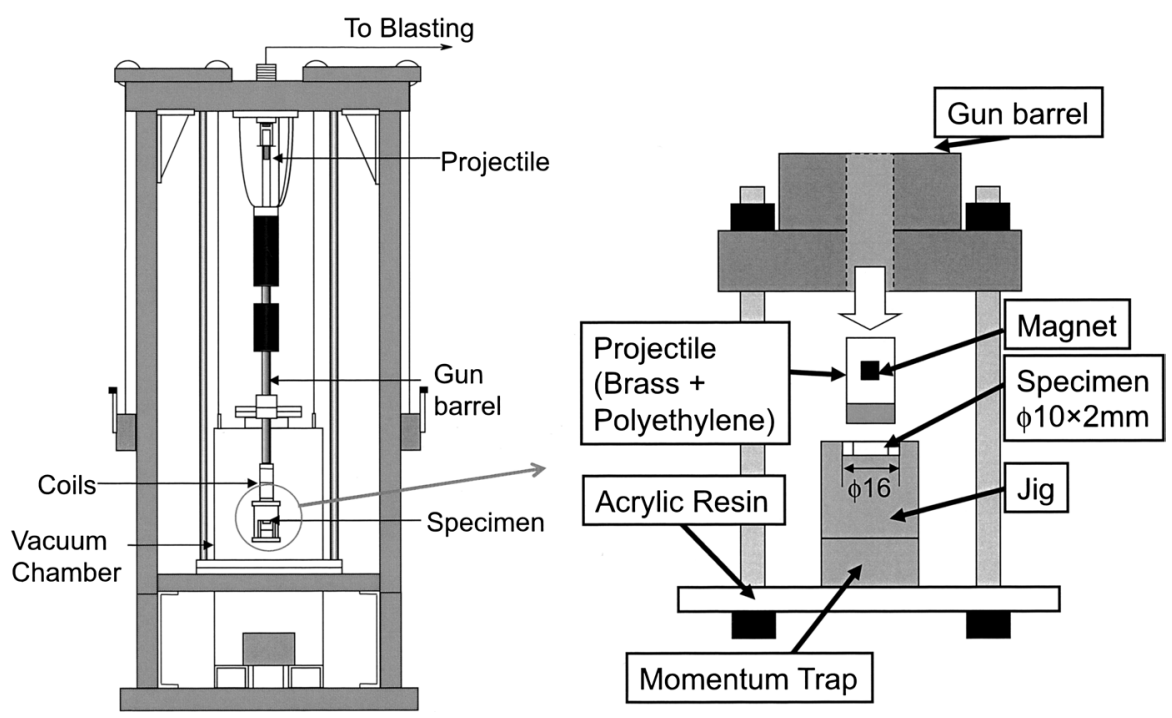

Fig. 1 Experimental setup used for high-speed deformation, using a single powder gun.

\section{2. 実験方法}

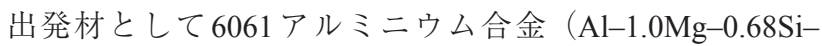
$0.28 \mathrm{Cu}$ ，質量％）押出丸棒材を用いた。丸棒材から直径 $10 \mathrm{~mm}$, 厚さ $2 \mathrm{~mm}$ の円板状試験片を切り出した。試験片は, $530^{\circ} \mathrm{C}$ で 90 分の溶体化処理-水焼入れを行った。溶体化処理 後の試験片の表面をエメリー紙研磨（\#1200）とバフ研磨（ア ルミナ粒子径： $0.3 \mu \mathrm{m}$ ) で鏡面とした。

円板試験片を Fig. 1 に示すような工具鋼からなる金型の 中に装填した後, 1 段火薬銃試験装置を用いて, 飛翔体の 高速平面衝突で円板試験片に対して高速圧縮変形を与えた。 飛翔体は先端が黄銅 $(\phi 15 \mathrm{~mm} \times 5 \mathrm{~mm})$, 胴体がポリエチレ ン $(\phi 15 \mathrm{~mm} \times 20 \mathrm{~mm})$ からなっており, 胴体内部には速度計 測用のフェライト磁石 $(\phi 7 \mathrm{~mm} \times 4 \mathrm{~mm})$ が埋め込まれている。 飛翔体先端の黄銅板が試験片に平面衝突する直前の速度を, 銃身の先端に取り付けてある3つのコイルで発生する起電力 の時間変化から求めた。火薬量を変化させることによって, 飛翔体速度を $450 \mathrm{~m} / \mathrm{s}$ （ひずみ速度 $2.3 \times 10^{5} \mathrm{~s}^{-1}$ に相当）から $650 \mathrm{~m} / \mathrm{s}$ （ひずみ速度 $3.4 \times 10^{5} \mathrm{~s}^{-1}$ に相当）の間で調整した。溶 体化処理終了後から高速圧縮変形までの時間は $0.5 \mathrm{~h}$ 以内と なるようにした。変形速度の影響を比較するために, 低速度 変形材料の比較材として, 冷間スエージング加工 $30 \%$ を与え た試験片も作製した。溶体化処理後に変形を与えた試料と与

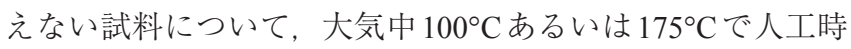
効処理を行った。時効時間に対するビッカース硬さ変化をも とに時効硬化曲線を作成した。透過電子顕微鏡（TEM）観 察については，まず時効後の試料表面をエメリー紙で $0.5 \mathrm{~mm}$ となるように研磨した。研磨した試験片をパンチで打ち抜い た後, ツインジェット法でTEM用サンプルを作成した。ツ インジェット法は, 電解液として硝酸 1 : メ夕ノール4の水 溶液中, $-40^{\circ} \mathrm{C}$ から $-20^{\circ} \mathrm{C}$ の温度範囲内で実施した。TEM観 察は, 日本電子株式会社製J JEM-2100F（加速電圧 $200 \mathrm{kV}$ ）で 行った。高速変形の有無による合金の引張特性を調查する ために, 円板状試験片から, 平行部長さ $2.9 \mathrm{~mm}$, 平行部幅 $1.0 \mathrm{~mm}$, 厚さ $3.0 \mathrm{~mm}$ となるように放電加工機を用いて微小 引張試験片を作製した。引張試験は室温大気中, 初期ひずみ
速度 $3.4 \times 10^{-3} \mathrm{~s}^{-1}$ で行った。引張試験後の破面を走査型電子 顕微鏡（SEM）で観察した。

\section{3. 実験結果および考察}

Fig. 2 に溶体化処理後に高速圧縮変形を与えた 6061 アルミ ニウム合金の $100^{\circ} \mathrm{C}$ 抢よび $175^{\circ} \mathrm{C} に$ 打ける時效硬化曲線を示 す（データの一部は文献8）からの引用）。比較のための冷 間スエージング加工材（低速変形）と未加工材の曲線も合わ せて示す。変形を与えた試料の硬さは, 変形前と比べて硬度 が2倍以上に上昇した。変形による硬さの増分 $\Delta \mathrm{Hv}$ は 48 $60 \mathrm{Hv}$ となった。この変形による初期硬さの増分は変形速度 の違いによらずほぼ同程度であった。しかしながら, その後 の $100^{\circ} \mathrm{C}$ 㧍よび $175^{\circ} \mathrm{C} て ゙ の$ 時効硬化については, 作用する変 形速度の違いによる挙動の変化が認められた。すなわち, 高 ひずみ速度で変形を与えた試料では, 低速変形試料と比べ て, その後の時効硬さが増加した。高速度変形では, その後 の $100^{\circ} \mathrm{C}$ 時効, あるいは $175^{\circ} \mathrm{C}$ 時効に扔いて, ピーク硬さ值 として，158 Hv, $136 \mathrm{Hv}$ をそれぞれ示した。このピーク硬さ 值の違いは, それぞれの時効温度に扔ける溶質元素の平衡溶 解度の違いに起因した析出相の体積分率の違いによるもので あると考えられる。一方, 低速度変形後の時効硬さの増分は 極めて小さく, 得られる最高硬さは, 時効前に加工を行わな かった試料とほほ同程度であった。したがって，本合金にお いても低速変形で導入される転位の存在によって時効硬化が 抑制されたと判断できる。

Fig. 3 に溶体化処理後の高速圧縮変形 $\left(10^{5} \mathrm{~s}^{-1}\right)$ の有無の 違いによる6061アルミニウム合金の TEM組織を示す。Fig. 3(b)に示す低倍率観察の結果, 高速圧縮変形後の試料では, 直径 $10 \mu \mathrm{m}$ 程度の結晶粒と $1 \mu \mathrm{m}$ 未満の結晶粒が混在してい る組織が観察された。しかしながら, 高速圧縮変形が結晶 粒微細化に及ぼす影響は，これまでに報告9) 12) されている ECAPやHPT などの準静的なひずみ導入プロセスと比べて小 さいことが明らかである。さらに, 今回の高速圧縮変形では 試験片の厚さ方向に $0.5 \sim 0.6$ の大きな軸ひずみが作用してい るにもかかわらず，組織の中に見られる転位の蓄積が必ずし も多くない傾向がみられた。したがって, 高速压縮変形で生 

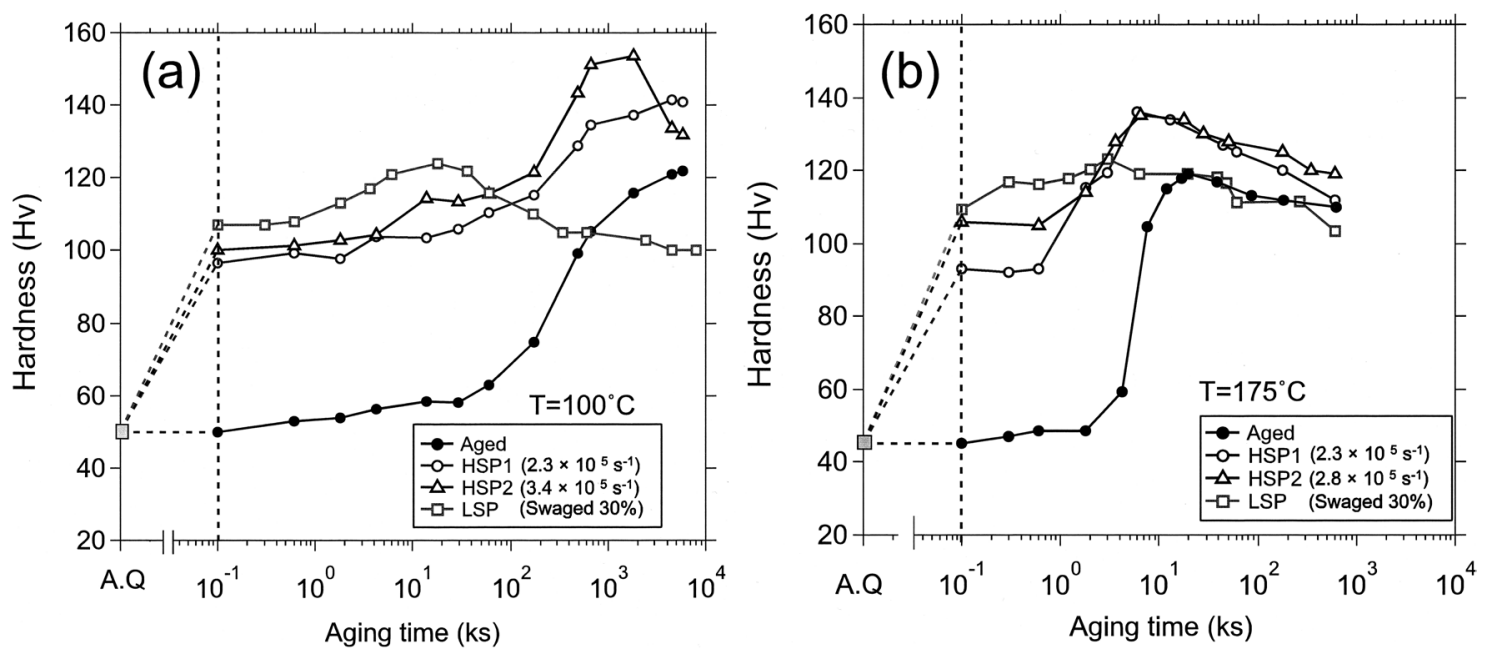

Fig. 2 Age-hardening curves for 6061 aluminum alloys aged at (a) $100^{\circ} \mathrm{C}$ and (b) $175^{\circ} \mathrm{C}$. HSP1: high-speed deformation 1 , HSP2: high-speed deformation 2, LSP: low-speed deformation.
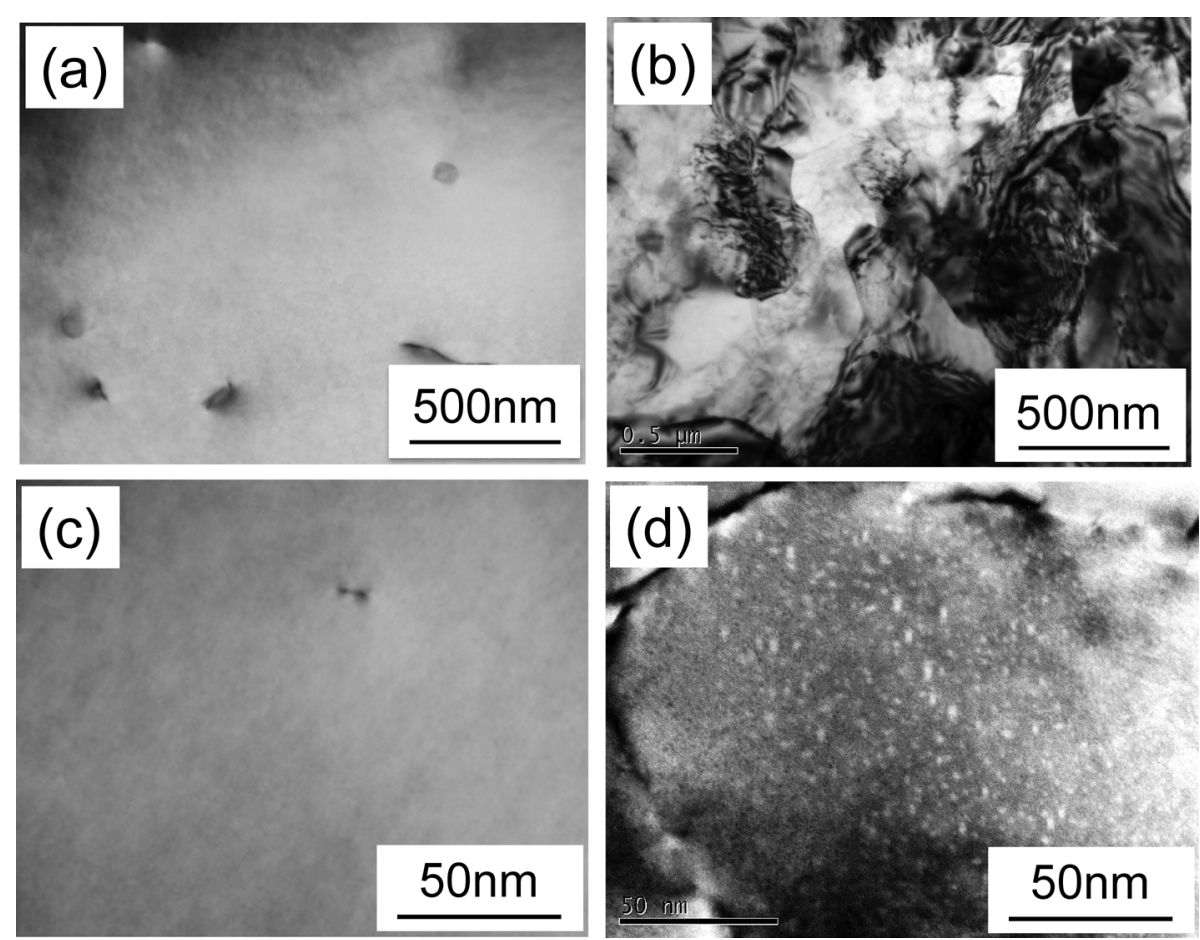

Fig. 3 Bright-field TEM images of 6061 aluminum alloys prepared without (a, c) and with (b, d) a high-speed deformation (2.3 $\left.\times 10^{5} \mathrm{~s}^{-1}\right)$.

じた顕著な硬さの上昇は結晶粒微細化や転位密度の上昇の作 用が主たる要因でないことは明らかである。さらに，同じ組 織に対して高倍率観察を行った結果を Fig. 3(c)(d) に示す。高 速圧縮変形を作用させると直径 $2 \sim 10 \mathrm{~nm}$ 程度の白色粒子が 結晶粒内に高密度に分布して扔り，変形を与えていない場合 はそのような組織は観察されなかった。本実験の TEM 観察 では加速電圧 $200 \mathrm{kV} て ゙$ 実施しており，同一組織に対して長 時間電子線を照射すると照射損傷によって同様の組織が生じ る可能性も考えられる。しかしながら, 今回高密度で観察さ れた白色粒子は，観察開始直後から分布しており，その形態 についても数分程度の電子線照射中においても大きく変化す ることはなかった。したがって，Fig. 3(d) に示した白色粒子 は高速度変形によって導入された点欠陥集合体であると判断 することができる。
Fig. 4 に溶体化処理後にひずみ速度 $2.3 \times 10^{5} \mathrm{~s}^{-1}$ で高速圧縮 変形を与えた 6061 アルミニウム合金の高分解能TEM像を示 す。拡大観察の結果から, 観察される点欠陥集合体は [ 1110$]$ から観察した場合に三角形形状を呈していることがわかっ た。したがって, 高速圧縮変形で導入される点欠樎集合体は 四面体構造を有していると判断できる。本実験で観察された 点欠陥集合体は Kiritani らによって報告 ${ }^{3)}$ されている積層欠 陥四面体（SFT）と同じものであろうと推測される。

Fig. 5 に，溶体化処理後に高ひずみ速度変形を与えてから， $175^{\circ} \mathrm{C}$ で $8 \mathrm{ks}$ のピーク時効処理を行った 6061 アルミニウム合 金（136Hv）のTEM 組織を示す。Fig. 5(a) に示す明視野像で

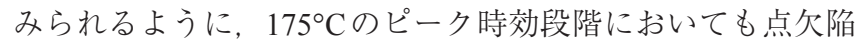
集合体は粒内に高密度に分布しており，また，形や大きさも 溶体化処理直後の状態とほとんど変化していなかった。した 
がって, 点欠陥集合体それ自体が $175^{\circ} \mathrm{C}$ の時効処理中に変化 して硬さの上昇分に寄与しているのではないと判断できる。 一方，Fig. 5(a) と同一視野を暗視像で観察したFig. 5(b) を見 ると, $\beta^{\prime \prime}-\mathrm{Mg}_{2} \mathrm{Si}$ 相と考えられる時効析出相が粒内に均一析出 していることが観察された。Fig. 5(a)(b)の対比により，高速 圧縮変形と $175^{\circ} \mathrm{C}$ 時効処理によって得られた高硬度 $(136 \mathrm{Hv})$ は, 点欠陷集合体による強化と析出強化の重畳作用によって もたらされたと考えられる。高ひずみ加工と時効析出の重 畳に関連して，ECAP加工を行った6061アルミニウム合金で は， $175^{\circ} \mathrm{C}$ で時効硬化を生じないことを $\operatorname{Kim} ら か ゙$ 報告 ${ }^{9)} し て$ いる。また，6061アルミニウム合金をHPT加工した場合も 同様に $170^{\circ} \mathrm{C}$ で時効硬化が見られないことを Matsudaらが報 告 ${ }^{3)}$ しているECAPおよびHPTの場合では，ナノサイズの 結晶粒界に時効硬化に関与しない析出相が不連続析出するこ とが示されている。一方, Fig. 5(b)に示す組織では, 点欠陥 集合体と粒内の時効析出相とが共存しており，それらは，過 去にECAPやHPT後の時効組織で観察されているものとは明 確に異なっている ${ }^{9), 10)}$ 。

Fig. 6 に高速圧縮変形の有無で比較した6061アルミニウム 合金 $175^{\circ} \mathrm{C}$ ピーク時効材の引張試験で得られた応力ーひずみ 曲線を示す。なお，Fig. 6に示したデー夕は，それぞれの条 件で 3 回実験を行った中で最も高い機械的特性を示した場合 のデータを示している。高速圧縮変形を作用させた試料の 耐力と引張強さはそれぞれ $395 \mathrm{MPa}, 420 \mathrm{MPa}$ であり，作用さ せなかった場合の耐力と引張強さのそれぞれの值 $285 \mathrm{MPa}$, $340 \mathrm{MPa}$ と比べていずれも高い值を示した。高速変形を与え
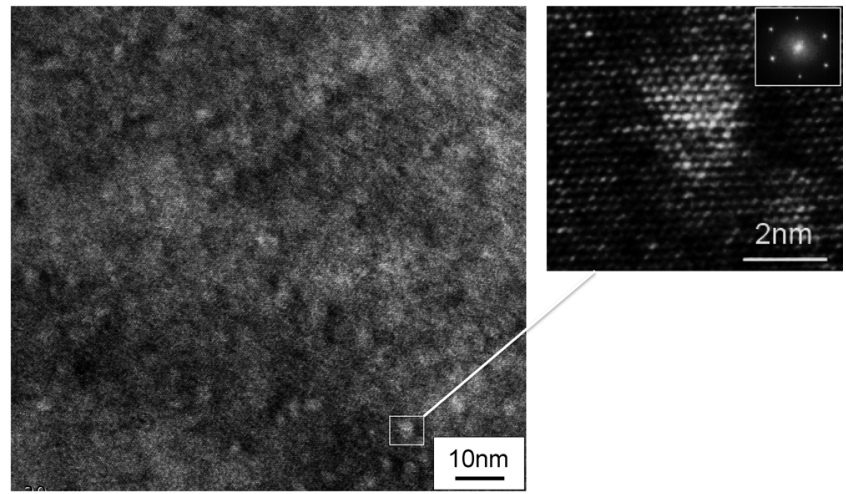

Fig. 4 High-resolution TEM image of a 6061 aluminum alloy prepared with high-speed deformation $\left(2.3 \times 10^{5} \mathrm{~s}^{-1}\right)$.
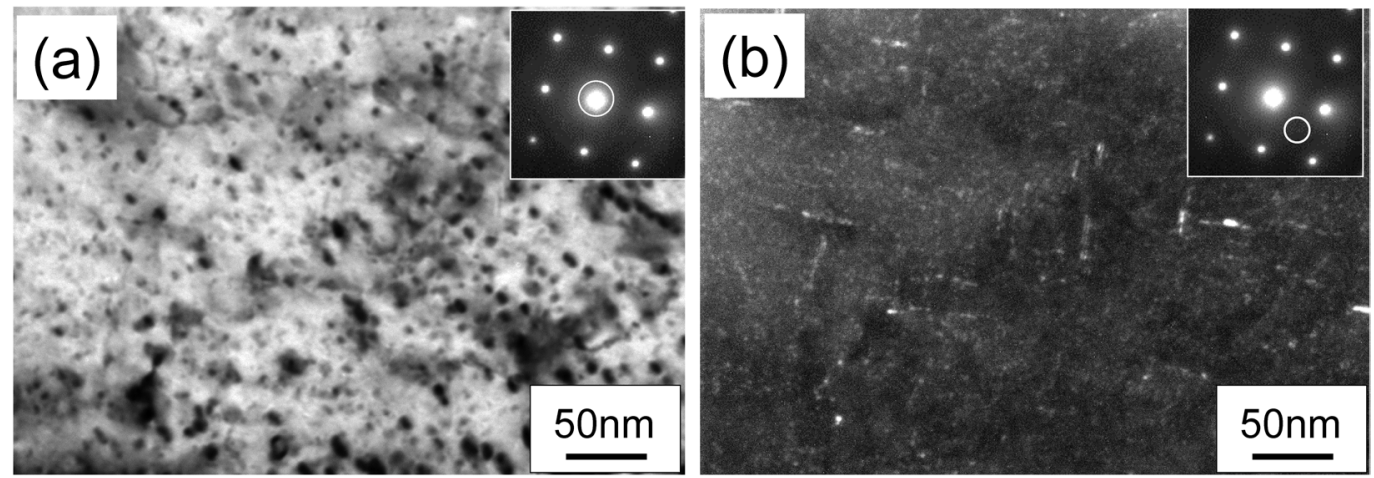

Fig. 5 (a) Bright and (b) dark field TEM images of the same regions of 6061 aluminum alloys prepared with high-speed deformation $\left(2.3 \times 10^{5} \mathrm{~s}^{-1}\right)$ and then peak-aged at $175^{\circ} \mathrm{C}$ for $8 \mathrm{ks}$.
た試料の強度（耐力と引張強さ）は，6061-T6アルミニウム 合金の標準值 ${ }^{13)}$ よりも高い值を示した。一方，高速変形を 作用させない場合，破断ひずみが 0.23 であるのに対して，高 速圧縮変形を作用させることで破断ひずみが 0.15 となり，延 性の低下は見られるものの，それでも良好な延性が保持さ れている。Fig. 7 に引張試験後の破断面の組織を示す。Fig 7(a)(b)に示す低倍率での観察により，破面中央部は，高速圧 縮変形の有無にかかわらず等軸ディンプルで覆われている が，表面近傍の破面端部においては，高速圧縮変形を作用し た試料のみ，せん断縁が観察された。破面中央部の等軸ディ ンプルの大きさは両試験片で大きな違いは認められなかっ た。つまり，高速圧縮変形を与えて強度上昇が生じた場合で も，破壊形態は，ボイドの生成と成長を伴う通常の延性ディ ンプル破壊を示すことが明らかである。

今回, 高速圧縮変形材でみられた高い時効硬化性は点欠陥 集合体による強化と析出強化という，2つの異なる強化機構 の重畳によって生じていると考えられる。そこで, 点欠陥集 合体が合金の強度に寄与する影響をボイド強化機構 ${ }^{14), 15)}$ で 提案されている次式(1) のボイド強化応力 $\sigma_{\mathrm{v}}$ を用いて考察 した。

$$
\sigma_{v}=M \tau_{v}=\frac{G b M}{2 \pi L_{v}}\left[\ln \left(D^{-1}+L_{v}^{-1}\right)^{-1}+B\right]
$$

ここで，Gはアルミニウムの剛性率 $(28 \mathrm{GPa}), b$ はバー

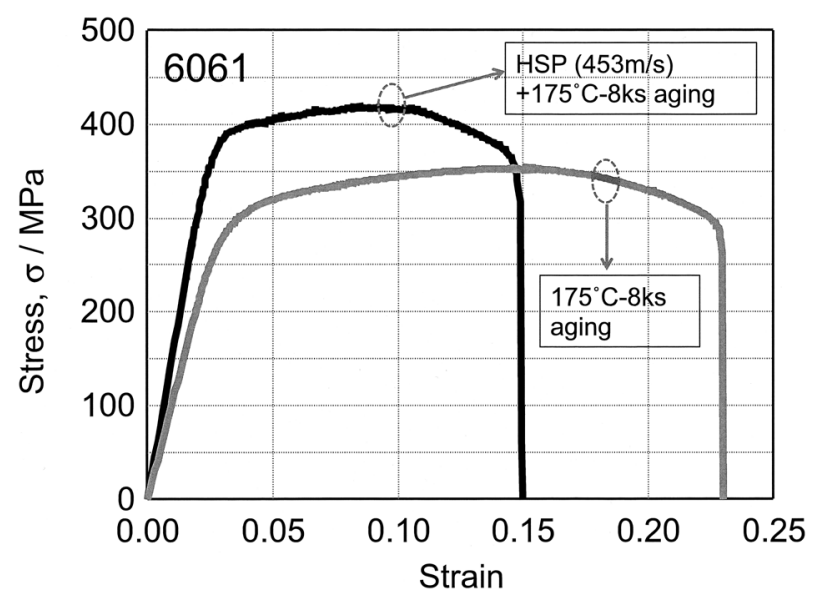

Fig. 6 Stress-strain curves of 6061 aluminum alloys prepared without and with high-speed deformation $(2.3$ $\times 10^{5} \mathrm{~s}^{-1}$ ) and then aged at $175^{\circ} \mathrm{C}$ for $8 \mathrm{ks}$. 

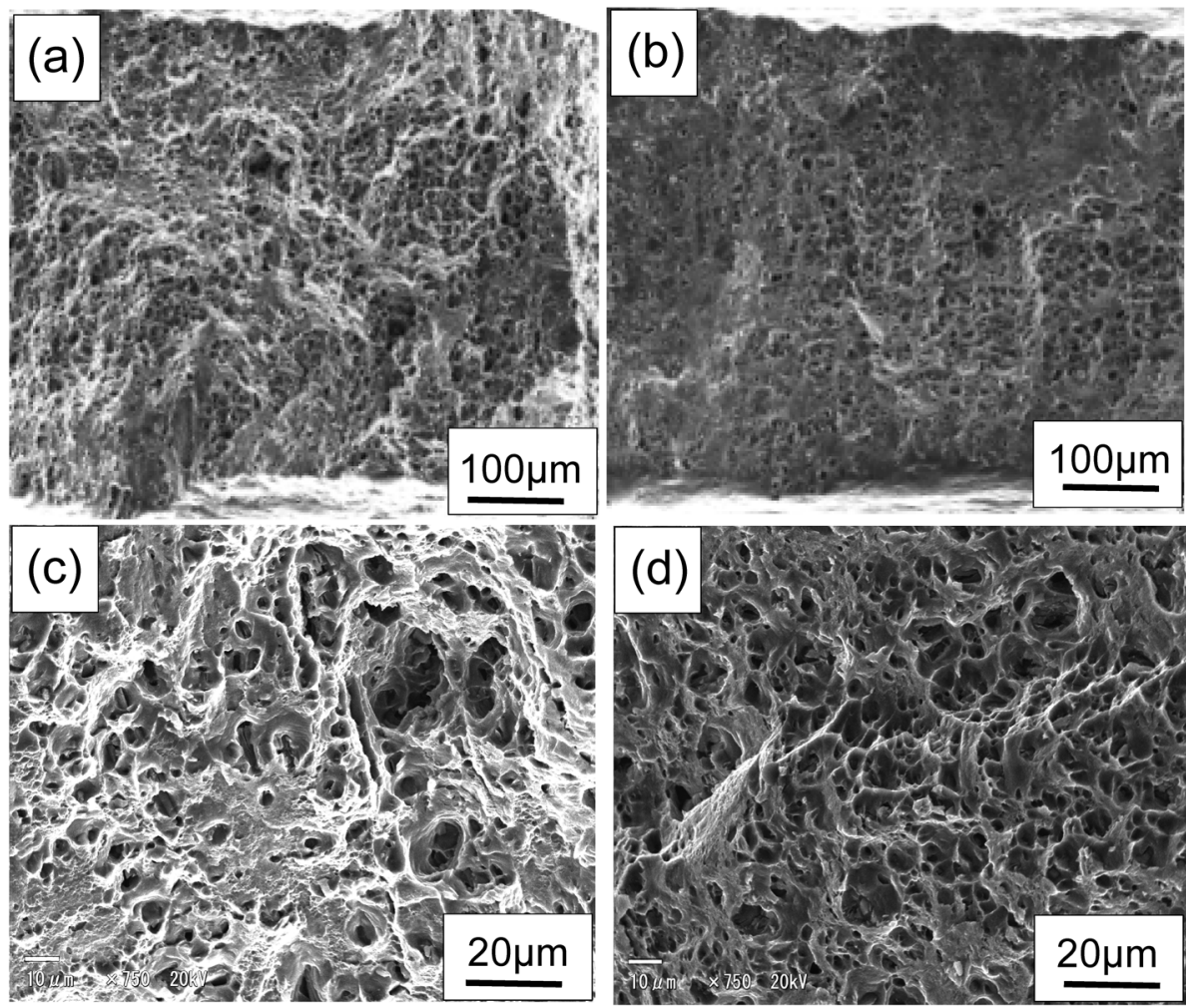

Fig. 7 Fracture surfaces of 6061 aluminum alloys prepared (a, c) without and (b, d) with high-speed deformation $\left(2.3 \times 10^{5} \mathrm{~s}^{-1}\right)$ and then aged at $175^{\circ} \mathrm{C}$ for $8 \mathrm{ks}$.

ガースベクトル $(0.28 \mathrm{~nm}), M$ はテイラー因子 $(3.06), D$ は ボイドの平均直径， $L_{\mathrm{v}}$ はボイド同士の距離，Bはボイドに関 する定数（1.52），䄈はボイド強化によるせん断応力である。 先にFig. 5(a)で示した組織を下に，DとLをそれぞれ $5 \mathrm{~nm}$, $50 \mathrm{~nm}$ として $\sigma_{\mathrm{v}}$ の大きさを求めると，その值は $116 \mathrm{MPa}$ とな る。一方, Fig. 6で示した引張試験の結果で示した耐力の増 分 $\Delta \sigma_{\mathrm{y}}$ は $110 \mathrm{MPa}$ となっており，式(1) で概算される值とほ ぼ同じ值を示した。したがって，式(1) を用いた点欠陥集合 体の強度増分への寄与の見積もりは，実際の強度増分をよく 表現していると言える。点欠陥集合体と時効析出という2つ の異なる強化機構の重畳については, それぞれの強化因子の 相互作用を考慮した評価が必要となると考えられるが，その 部分については今後の検討課題としたい。

\section{4. 結言}

$6061 ア ル ミ ニ ウ ム$ 合金の時効硬化特性および組織に及ぼ す高速圧縮変形の影響を調査した結果，次のような結論を得 た。

（1）溶体化処理後にひずみ速度 $10^{5} \mathrm{~s}^{-1}$ に相当する高速で 圧縮変形を作用させると，結晶粒内部に高密度の点欠陥集合 体が観察される。

（2）高速圧縮変形後の $100^{\circ} \mathrm{C} や 175^{\circ} \mathrm{C}$ の時効処理によっ て, ピーク時効硬さが未加工材や低速変形材と比べて大きく 増加する。

（3）高速圧縮変形と時効処理によって得られた高いピー ク硬度は, 点欠陥集合体強化と析出強化の重畳作用によって
生じたものである。

本研究の費用の一部は, 公益財団法人軽金属奨学会の平 成 25 年課題研究の研究助成により行われたものです。また, 電子顕微鏡の利用にあたり大阪大学接合科学研究所の共同研 究制度を利用させていただきました。記して謝意を表しま す。

\section{参 考 文 献}

1) D. Hull and D. J. Bacon eds.: Introduction to Dislocations, Elsevier, (2001), 99-101.

2) M. Kiritani: Radiat. Effect. Defect. Solids, 157 (2002), 1-24.

3) M. Kiritani: Mater. Chem. Phys., 50 (1997), 133-138.

4) H. Ohkubo, Y. Shimomura, I. Mukouda, K. Sugio and M. Kiritani: Mater. Sci. Eng. A, 350 (2003), 30-36.

5) M. Kiritani: Mater. Sci. Eng. A, 350 (2003), 1-7.

6) M. Kiritani: Mater. Sci. Eng. A, 350 (2003), 63-66

7) Y. N. Osetsky and D. J. Bacon: J. Nucl. Mater., 323 (2003), 268-280.

8) K. Horikawa, Y. Kitani, T. Ogura, A. Hirose, M. Takahashi and H. Kobayashi: Mater. Sci. Forum, 794-796 (2014), 778-783.

9) J. K. Kim, H. G. Jeong, S. I. Hong, Y. S. Kim and W. J. Kim: Scr. Mater., 45 (2001), 901-907.

10) T. Masuda, S. Hirosawa, Z. Horita and K. Matsuda: J. Jpn. Inst. Met., 75 (2011), 283-290.

11) Z. Horita, S. Hirosawa, K. Matsuda and D. Terada: J. Jpn. Inst. Light Met., 62 (2012), 398-405.

12) N. Tsuji, T. Toyoda, Y. Minamino, Y. Koizumi, T. Yamane, M. Komatsu and M. Kiritani: Mater. Sci. Eng. A, 350 (2003), 108-116.

13) Japan Aluminum Association eds.: Aluminum Handbook, (2007), 100.

14) Y. N. Osetsky and D. J. Bacon: Philos. Mag., 90 (2010), 945-961.

15) D. Terentyev, D. J. Bacon and Y. N. Osetsky: J. Phys. Condens. Matter., 20 (2008), 445007. 